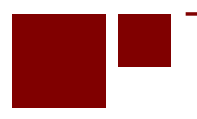

\title{
DO HOUSEHOLDS INCREASE THEIR SAVINGS WHEN THE KIDS LEAVE HOME?
}

\author{
Irena Dushi, Alicia H. Munnell, Geoffrey T. Sanzenbacher, Anthony Webb, and Anqi Chen
}

CRR WP 2015-26

September 2015

\author{
Center for Retirement Research at Boston College \\ Hovey House \\ 140 Commonwealth Avenue \\ Chestnut Hill, MA 02467 \\ Tel: 617-552-1762 Fax: 617-552-0191 \\ http://crr.bc.edu
}

Irena Dushi is an economist in the Office of Retirement and Disability Policy at the Social Security Administration (SSA). Alicia H. Munnell is the Peter F. Drucker Professor of Management Sciences at Boston College's Carroll School of Management and director of the Center for Retirement Research at Boston College (CRR). Geoffrey T. Sanzenbacher is a research economist and Anthony Webb is a senior research economist at the CRR. The research reported herein was performed pursuant to a grant from the SSA funded as part of the Retirement Research Consortium. The opinions and conclusions expressed are solely those of the authors and do not represent the opinions or policy of SSA, any agency of the federal government, or Boston College. Neither the United States Government nor any agency thereof, nor any of their employees, makes any warranty, express or implied, or assumes any legal liability or responsibility for the accuracy, completeness, or usefulness of the contents of this report. Reference herein to any specific commercial product, process or service by trade name, trademark, manufacturer, or otherwise does not necessarily constitute or imply endorsement, recommendation or favoring by the United States Government or any agency thereof. The authors would like to thank Anqi Chen for excellent research assistance. Part of this analysis was first performed using the SIPP Synthetic Beta (SSB) on the Synthetic Data Server housed at Cornell University which is funded by NSF Grant \#SES-1042181. These data are public use and may be accessed by researchers outside secure Census facilities. For more information, visit http://www.census.gov/programs-surveys/sipp/methodology/sipp-synthetic-beta-data-product.html. Final results for this paper were obtained from a validation analysis conducted by Census Bureau staff using the SIPP Completed Gold Standard Files and the programs written by this author and originally run on the SSB. The validation analysis does not imply endorsement by the Census Bureau of any methods, results, opinions, or views presented in this paper.

(C) 2015, Irena Dushi, Alicia H. Munnell, Geoffrey T. Sanzenbacher, and Anthony Webb. All rights reserved. Short sections of text, not to exceed two paragraphs, may be quoted without explicit permission provided that full credit, including (C) notice, is given to the source. 


\begin{abstract}
About the Center for Retirement Research
The Center for Retirement Research at Boston College, part of a consortium that includes parallel centers at the University of Michigan and the National Bureau of Economic Research, was established in 1998 through a grant from the Social Security Administration. The Center's mission is to produce first-class research and forge a strong link between the academic community and decision-makers in the public and private sectors around an issue of critical importance to the nation's future. To achieve this mission, the Center sponsors a wide variety of research projects, transmits new findings to a broad audience, trains new scholars, and broadens access to valuable data sources.
\end{abstract}

Center for Retirement Research at Boston College

Hovey House

140 Commonwealth Ave

Chestnut Hill, MA 02467

Tel: 617-552-1762 Fax: 617-552-0191

http://crr.bc.edu

Affiliated Institutions:

The Brookings Institution

Massachusetts Institute of Technology

Syracuse University

Urban Institute 


\begin{abstract}
Much of the disagreement over whether households are adequately prepared for retirement reflects differences in assumptions regarding the extent to which consumption declines when the kids leave home. If consumption declines substantially when the kids leave home, as some life-cycle models of retirement saving assume, households need to achieve lower replacement rates in retirement and need to accumulate less wealth. Using administrative tax data from the Health and Retirement Study (HRS), as well as the Survey of Income and Program Participation (SIPP), this paper investigates whether household consumption declines when kids leave the home and, if so, by how much. Because consumption data are noisy and savings is the flip side of consumption, this paper examines whether savings in 401(k) plans increase when the kids leave home. The paper also investigates alternative methods of saving, including non401(k) savings and increased mortgage payments.
\end{abstract}

This paper found that:

- Households increase contributions to $401(\mathrm{k})$ plans by 0.3-0.7 percentage points when the kids leave home.

- The finding is significant across datasets and for alternative definitions of the kids leaving home.

- The increase in 401(k) contributions, however, is only a fraction of that predicted by lifecycle models that assume consumption declines substantially when the kids leave.

- Home-owning households whose kids leave home are also less likely to have a mortgage than other households - suggesting higher post-kid payments - but the amount of increased savings implied is again much smaller than predicted by the life-cycle model.

The policy implications of this paper are:

- Most households will not be able to maintain their pre-retirement standard of living.

- $\quad$ Retirement saving needs to increase. 


\section{Introduction}

Academic opinion differs as to whether the United States faces a retirement savings crisis. Some researchers argue that only half of households will be able to maintain their customary spending level in retirement (Mitchell and Moore 1998, Munnell, Orlova, and Webb 2013). Others argue that maintaining consumption is an overly ambitious and indeed suboptimal goal. Drawing on economic theory, they contend that households should set a goal, not of smoothing consumption, but of smoothing the marginal utility of consumption. If consumption needs, and thus the marginal utility of consumption, are higher while the kids are at home, then households should optimally plan for higher consumption then and lower consumption after the kids leave home and in retirement (Scholz and Seshadri, 2006, 2008). An important corollary of lower consumption when the kids leave home is that most retirement savings will take place just before retirement.

The two theories presented above have very different implications for whether or not we face a retirement savings crisis. If savings spike after the kids leave home, we likely do not face a widespread retirement saving crisis. But if households do not increase savings, many will arrive at retirement with insufficient resources to maintain the higher per capita standard of living they became accustomed to after the kids left. The question is which of these two possibilities best describes household behavior?

To answer this question, this paper uses data from the Health and Retirement Study (HRS) linked to W-2 tax records to examine whether 401(k) contributions spike when the kids leave home. The analysis is conducted both in the pooled cross section, i.e., comparing similar households that differ as to whether the kids have left, and using fixed effects, i.e., comparing 401(k) savings for the same household before and after the kids leave. Because some households will support non-resident kids while they are in school, we use various definitions of the kids leaving home, some of which consider college students as still present. For the majority of households that save little outside of their 401(k), the W-2 tax records yield a highly accurate measure of total saving in financial assets. But, of course, not all saving is conducted through 401(k)s, so this paper also investigates the effect of the kids leaving on non-401(k) wealth and mortgage payments. Another concern is that the HRS contains households where the head is age 50 or older, and therefore the results may not reflect the behavior of the broader population. We therefore supplement the HRS analysis of 401(k) contributions with a pooled-cross-section 
analysis of Survey of Income and Program Participation (SIPP) data, again using administrative tax data.

The results show a small increase of 0.3 to 0.7 percentage points in 401(k) contributions as a share of earnings around the time the kids leave home, depending on the specification and dataset being considered. This result holds for both the HRS pooled-cross-section and fixedeffects models and in the pooled-cross-section analyses conducted in the SIPP. While in most specifications (aside from the fixed-effect models) this increase is statistically significant, the magnitude of the increase is only a fraction of that implied by models that assume the marginal utility of consumption is higher when the kids are at home.

Regarding other assets, while we find no evidence that households increase non-401(k) savings when the kids leave home, we do find that households owning their own homes and whose kids have left are 7 to 8 percentage points less likely to carry mortgage debt. While this fact is consistent with such households pre-paying their mortgages, a form of increased savings, we estimate that the average extra amount saved by households in this form is just an additional 2 percent of earnings per year, again much smaller than would be predicted by the life-cycle model. We conclude that if households are behaving in a manner consistent with models that assume large declines in consumption when the kids leave, they are not doing so by increasing 401(k) contributions, by increasing non-401(k) financial assets, or by paying down mortgage debt.

The remainder of the paper is organized as follows. The first section describes the life cycle model and reviews relevant literature. The second section describes the data. The third section presents the empirical methodology. The fourth section presents our results, and the fifth section concludes.

\section{Life Cycle Model and Literature Review}

The life cycle model is an especially relevant tool for describing retirement savings behavior, because it prescribes optimal paths of saving and consumption that maximize expected lifetime utility and is therefore a frequent topic in the academic literature. 


\section{Life Cycle Model}

Financial planners often think in terms of replacement rate targets - households should try to save sufficient amounts to achieve a target replacement rate that will permit them to maintain their standard of living. Economists, on the other hand, do not typically think in terms of replacement rate targets, but instead postulate that households should select an asset accumulation and decumulation plan that maximizes expected discounted lifetime utility, subject to a budget constraint - a life cycle model of saving. Assuming that consumption and leisure are separable in the utility function ${ }^{1}$ and ignoring mortality risk, the optimal consumption path is one that satisfies the following first-order condition:

$$
u^{\prime}\left(c_{t}\right)=\beta E_{t}\left[\left(1+r_{t+1}\right) u^{\prime}\left(c_{t+1}\right)\right]
$$

where $r$ is the rate of interest. The household will choose a consumption path such that the marginal utility of this period's consumption equals the expected marginal utility of next period's consumption, discounted by a rate of time preference, and multiplied by 1 plus the rate of interest. The intuition is that the household cannot increase total utility by shifting consumption from one period to another.

If the rate of interest equals the rate of time preference, and if the marginal utility of consumption does not vary with the number of resident kids, then in the absence of risk the household would choose a savings plan that provides level consumption over the lifecycle. ${ }^{2}$ On the other hand, if the marginal utility of consumption is higher when kids are present, then households will optimally plan for higher consumption when the kids are at home and lower consumption after the kids have left home and in retirement. Many life-cycle models assume that the marginal utility of consumption is higher when the kids are home, effectively imposing a time path of consumption that is high when the kids are at home and much lower when they move out. In contrast, target replacement rate calculations, such as those of the Georgia State RETIRE Project (Palmer, 2008) and those used in the National Retirement Risk Index compiled by the Center for Retirement Research (Munnell, Webb, and Delorme, 2006), implicitly assume

\footnotetext{
${ }^{1}$ Separability implies that the marginal utility of consumption does not depend on the amount of leisure.

${ }^{2}$ In practice, households face both liquidity constraints and investment, labor market, and mortality risks that will affect the optimal consumption path.
} 
the marginal utility of consumption does not change when the kids leave home. As a result, both the Georgia State and National Retirement Risk Index calculations assume no change in consumption when the kids leave home. It is an empirical question which assumption is correct, and the answer has large implications for the literature on the financial preparedness of individuals approaching retirement.

\section{Literature Review}

Calculations of financial preparedness for retirement based on target replacement rates tend to show that about half of working age households are financially prepared. Using Survey of Consumer Finances (SCF) data, Munnell, Rutledge, and Webb (2014) estimate that fewer than half of households age 30-59 in 2013 will be able to maintain their standard of living in retirement even if they retire at age 65, annuitize their financial assets, and take out a reverse mortgage. Using HRS data, Munnell, Orlova, and Webb (2013) estimate that only 48 percent of working households approaching retirement will be able to achieve their replacement rate targets if they retire at age 65.

In contrast, Scholz and Seshadri (2006, 2008), using an intertemporal optimization model and the same HRS data, arrive at much more optimistic conclusions. Scholz, Seshadri, and Khitatrakun (2006) estimate that only 16 percent of households born between 1931 and 1941 had saved less than optimal amounts by 1992, when they were ages 51-61, given the shocks they had experienced. With the benefit of hindsight, households that experienced adverse labor market outcomes might wish that they had saved more, but ex-ante, few households had undersaved. Scholz and Seshadri (2008) extend the above analysis to include more recent data and subsequent birth cohorts and again find a low percent of households had undersaved.

One of the major reasons for these large differences is how the various papers treat kids. In contrast to Munnell, Rutledge, and Webb (2014), Scholz and Seshadri assume that households optimally plan to enjoy higher consumption when the kids are at home and lower consumption both after the kids have left home and in retirement when they have fewer mouths to feed. Specifically, they assume the following equivalence scale proposed by Citro and Michael (1995):

$$
n_{j}=\left(A_{j}+0.7 K_{j}\right)^{0.7}
$$


where $\boldsymbol{n}$ is the household's needs, $A$ denotes adults, and $K$ denotes kids. This equivalence scale implies a dramatic decline in consumption once the kids leave home and an implied increase in savings of about 20 percent of earnings. As the Scholz and Seshadri households plan to enjoy lower consumption not only after the kids leave home but also in retirement, they need to accumulate less financial wealth. Furthermore, most of what little saving they do should take place in the interval between the kids leaving home and retirement.

The treatment of kids has a non-trivial effect on estimates of retirement preparedness. Munnell, Rutledge, and Webb (2014) show that differences in the treatment of kids explain about half of the difference in the estimates of the percent of households with inadequate savings. For HRS households age 51-61 in 2004, Scholz and Seshadri (2008) report that 8 percent of these households have saved sub-optimally. In contrast, Munnell, Rutledge, and Webb (2014) estimate that 35 percent will be unable to hit their replacement rate targets. Half of the 26percentage points - 13 percentage points - reflects differences in the treatment of kids. ${ }^{3}$

The literature on whether consumption drops when kids leave home is scant and inconclusive. Coe and Webb (2010) examine this question using HRS Consumption and Activities Mail Survey (CAMS) data. They found no evidence that households decreased total consumption when the kids left home. But the sample size was relatively small, and HRS consumption data suffer from both non-response and reporting error. On the other hand, Klos and Simon (2013), using German data, find a moderate decrease in consumption and increase in saving when the kids leave home.

We therefore adopt an alternative approach of testing for changes in saving rather than for changes in consumption. Because all income is consumed, saved, or taxed, holding income and taxes constant, if households increase saving, they must be decreasing consumption. The advantage of this indirect approach is that both earnings and savings in 401(k) plans can be measured using tax data - in W-2 forms. Although households can also save outside of their 401(k) plans, most have relatively small non-IRA/401(k) balances. Still, to address this

\footnotetext{
${ }^{3}$ Most of the remainder is the result of differences in drawdown. Munnell, Rutledge, and Webb (2014) assume that households purchase an inflation-indexed annuity. Scholz and Seshadri $(2006,2008)$ assume that households undertake an optimal drawdown of unannuitized wealth. They optimally choose a declining consumption path, reflecting a preference for greater consumption at ages at which they are more likely to be alive. Given their assumed intertemporal elasticity of consumption, they require less wealth per dollar of age-65 consumption than purchasers of inflation indexed annuities, and therefore optimally accumulate less wealth.
} 
possibility we examined whether non-401(k) savings increased after the kids leave and also look at another form of savings that may be common, pre-paying a mortgage.

Our paper builds on a literature that investigates the frequency and determinants of changes in 401(k) elective deferrals. Using SIPP data linked to W-2 tax records, Smith, Johnson, and Muller (2004) found that contributions fluctuated considerably over time. They found some evidence that contribution rates responded to life events, but the magnitude of the responses was generally small. In contrast, Utkus and Young (2009) found that participants rarely changed their asset allocations or stopped elective deferrals.

\section{Data}

Our primary analysis uses data from the 1992-2010 waves of the HRS linked to W-2 tax records. Because the HRS allows estimation using only individuals over age 50, we supplement this main analysis with the 1992-2008 panels of the SIPP to check whether the savings behavior of HRS households is similar to that of younger parents.

\section{Health and Retirement Study}

The HRS is a panel survey of households where the head is age 50 or older that has been administered every two years since 1992. The survey collects in-depth information on income, work histories, assets, pensions, health insurance, disability, physical health and functioning, cognitive function, and health care expenditures. The goal of the HRS analysis is to examine how households' 401(k) contributions respond when kids leave home. The sample consists only of households containing a married couple who remain intact throughout the entire observed period and who were successfully linked to their $\mathrm{W}$-2 records.

This initial sample comprises 10,473 households whose head was under age 70 at the first wave they were observed, or 104,370 household wave observations. We discard 13,160 wave observations for households who did not work for pay between 1992 and 2010, reducing the sample to 91,210 household wave observations. We restrict the sample to households that participated in a 401(k) plan at some time during the above period, reducing the sample to 
16,835 household wave observations. ${ }^{4}$ We further restrict the sample by eliminating households where one or both spouses were working for pay but did not consent to having their W-2s linked to the HRS, yielding a final sample of 11,186 . We follow this final sample until the earliest of 2010 or the wave prior to a change in marital status, whichever occurs first, and we include only waves where the household was working for pay, yielding 10,950 household-wave observations. Another 107 household wave observations were excluded due to data inconsistencies resulting in a final sample of 10,843 household wave observations, or 3,324 households.

We consider three definitions of kids living at home. The first is having kids that physically live at home, regardless of age. However, this first definition suffers from an important omission: kids who have left the home but are residing at college. Since the purpose of identifying resident kids is to provide a proxy for identifying households with financially dependent kids, our second definition includes kids who moved out of the household but are still in school. This definition essentially assumes all children in college are financially dependent, even though some kids attending college may be financially independent. We therefore consider a third definition in which kids in college are excluded if, at a prior interview, they were neither physically resident nor attending college. Table 1 shows the allocation of households among categories by the definition of kids leaving home and indicates that the first definition is the most restrictive because it assumes kids who may be in college but do not live at home are not in the household.

Using this first definition of kids leaving home, Table 2 compares the socioeconomic characteristics of the four groups of married couples. Those whose kids have left home were about five years younger when their first child was born than those with resident kids. Married couples who never had kids have the most education, and those whose kids have already moved out have the least education. Couples who never had kids have significantly higher earnings than those with kids. This pattern likely reflects differences in educational attainment but may also reflect differences in labor supply decisions, underscoring the need to control for both education

\footnotetext{
${ }^{4}$ One alternative would be to estimate the model on all households, regardless of whether they were eligible for a 401(k). But this would bias downward our estimate of the effect of kids leaving home, because some of these households are ineligible for a $401(\mathrm{k})$ and could not increase contributions even if they wanted to. Another alternative would be to condition on participation. But this would also bias downward our estimates if participation is one of the margins on which households adjust consumption. Yet another approach would be to condition on eligibility. But this might bias our results if households select into jobs offering 401(k) plans based on their taste for saving. Our approach is intended to identify households that have some opportunity to find a job that offers a 401(k) plan.
} 
and income in our regressions. Those with kids have similar wealth levels regardless of whether the kids are in residence. One explanation is that the two groups are indeed similar. An alternative explanation is that the households whose kids have left home are saving more, but the effects are offset in this cross-sectional analysis by their lower income and educational attainment. While it requires multivariate analysis to identify the separate effects, this analysis is complicated by the structure of our data. While the W-2 data reports earnings and 401(k) contributions per calendar year, ${ }^{5}$ the residence status of kids is only observed at the interview date. We only know that the kid moved out between one wave and the next, but not the date they moved out. We assume that if kids were present at interview $t$ - 1 , they were present throughout the calendar year in which the interview took place. If they were absent at interview $t$, we assume they were absent throughout that calendar year.

\section{Survey of Income and Program Participation}

To augment the main HRS analysis, we use data from the Survey of Income and Program Participation (SIPP) and again investigate whether workers whose kids are no longer resident save more through their 401(k)s than households with resident kids. The SIPP has one major disadvantage relative to the HRS: its short-panel design - even the longest SIPP panels typically last at most five years. This design makes it difficult to do the kind of longitudinal analysis being conducted in the HRS where many individuals have 15 to 20 years of data. However, the SIPP offers one major advantage over the HRS - the sample includes younger individuals. This allows us to check that our HRS results apply equally to younger parents.

The SIPP analysis uses the 1992-2008 panels, reflecting a similar time period as is investigated in the HRS. In the public-use SIPP, each individual in a household is interviewed every four months over the two to five years in their panel about a wide range of topics, including labor market outcomes, public program participation, demographics and family structure, and health insurance coverage. But in the public-use data, contributions to 401(k)s are based on self-report and thus it is unclear the results would be directly comparable to those from the HRS, which use administrative data. Instead, the analysis in this paper relies on SIPP data made available through the U.S. Census's SIPP Synthetic Beta (SSB) project. In the SSB, a

\footnotetext{
${ }^{5}$ In contrast, HRS participants self-report current 401(k) contributions and earnings for the last calendar year. We assume that current year earnings equal those for the last year and the base current and last year's 401(k)

contributions on the current contribution rate.
} 
subset of essential SIPP variables is linked, via Social Security Number, to an SSA-produced extract from W-2 tax records, including an individual's total annual tax-deferred earnings for each year from 1978-2010. ${ }^{6}$ These data also include individuals' age, the age of their first and last born children, their level of education, ownership of a home, race and ethnicity, and the availability of defined benefit and defined contribution plans at work. ${ }^{7}$ Importantly, the data allow matching of any individual in the data to their first spouse during their time in any SIPP panel. $^{8}$

As in the case of the HRS, the SIPP analysis focuses only on married couples. The sample starts with 121,682 married-couple households where at least one individual was aged 18 to 70. The dependent variable is the percent of the household's earnings contributed to defined contribution pensions. Thus, the sample is restricted to households where at least one individual is earning income, reducing the sample to 103,621 households. The sample is also restricted to only households where at least one member has access to a 401(k) plan at work, further reducing the sample to 41,138 households. The key independent variable in this paper is whether or not a household with kids still has some kids residing in the home. In the SIPP data being used, the only data available indicative of kids' presence in the household is the age of the last child born, so our approach using the SIPP data simply controls for the youngest child's age. Controls are included for households who never had any children, who have a youngest child 18 and under (approximating children present), who have a youngest child between 19 and 22 (approximating children potentially in college), and age 23 and over (approximating out of college). ${ }^{9}$ Although such an approach is not a perfect definition of the kids leaving home, the results will serve as a useful check on the HRS. The final sample consists of 40,388 households for whom child birthdate data were complete.

\footnotetext{
${ }^{6}$ The SSB alleviates privacy disclosure concerns by allowing researchers to first run their analysis on synthesized data and then, through a U.S. Census employee, re-run the analysis on actual data. The synthetic data aim only to match unconditional means of the public-use SIPP variables, so conditional analysis for selected subsamples is not meaningful. With this consideration, the results reported in this paper are the average of the estimates produced from the Completed Data Files; other than imputed values, therefore, the analysis uses actual, not synthetic, data. ${ }^{7}$ Because the administrative data used do not have information on mortgage payments or non-401(k) savings, only the 401(k) analysis is conducted in SIPP.

${ }^{8}$ Although, in theory, the availability of data on earnings from 1978-2010 would allow a longitudinal analysis, it would be impossible to determine marital status or the individual's spouse at any time other than during the individual's time in the panel.

${ }^{9}$ Again, all children variables are based on the female. If the male had children with a different woman, it is implicitly assumed that the children resided with the mother.
} 
Table 3 offers descriptive statistics separately for households who never had kids, households with kids under 18, households with kids aged 19-22, and finally for households with kids 23 and over. Households whose kids are older are generally older than households with younger kids, tended to have their kids earlier, have slightly less education, and are slightly more likely to own their homes. Compared to the HRS sample, the SIPP sample is about eight years younger on average and has slightly higher average earnings with very similar median earnings. The SIPP and HRS samples are similar in terms of education level, minority status, and homeownership. In the SIPP sample, households who have kids over age 23 contribute a higher share of their income to defined contribution plans than workers with younger kids, although this may reflect their greater average age.

\section{Empirical Methodology}

We use two empirical methodologies: 1) a cross-sectional model in which individuals with kids present are compared to similar individuals where kids are not present; and 2) a fixedeffects model examining within-household variation in contributions before and after the kids leave the home. The HRS data are used for both analyses, and the SIPP, which does not track households over long periods of time, only for the cross-sectional component.

\section{Pooled Cross-section Model}

In the pooled cross-sectional models, the dependent variable is the contribution rate as a percent of salary. The cross-sectional models take the following form:

$$
S_{i, t}=\alpha_{0}+\alpha_{1} \text { NoKids }_{i,}+\alpha_{2} \text { KidsGone }_{i, t}+\alpha_{3} Y_{i, t}+\gamma X_{i, t}+\varepsilon_{i, t}
$$

where $S_{i, t}$ is the contribution rate. In equation (1), the independent variables are NoKids$s_{i}$, indicating that the household never had any kids; ${ }^{10} K_{i d s G o n e}, t$, indicating that all of the individual's kids had left home by time $t ; Y_{i, t}$, household labor market earnings; and $X_{i, t}$ which is a vector of socio-economic, demographic, and other variables, including the ethnicity, age, and educational attainment of the household head. If households with kids consume more while the

\footnotetext{
${ }^{10}$ We obtained similar results with a model that controlled for the number of resident children.
} 
kids are there and cut back later, the $\alpha_{2}$ coefficient should be positive and significant. If the childless also save more because they optimally target higher replacement rates, the $\alpha_{1}$ coefficient should be positive and significant. Because households may increase savings through other avenues aside from a 401(k), equation (1) is also estimated on non-401(k) savings and using an indicator for the presence of a mortgage. The interpretation of the coefficients is similar.

\section{Fixed-effect Model}

Equation (1) does not control for potential biases resulting from any unobserved differences in household characteristics that may be correlated with both savings and the presence of kids. For example, if households that save more also have kids later, then the coefficient on resident kids, $\alpha_{2}$, may be biased downward since the kids in these families may still be resident. To deal with this issue, we re-estimate equation (1), including a household fixed-effect. The fixed-effect model will also include a time trend, to control for the possibility that 401(k) deferrals are increasing over time for reasons unconnected with the kids leaving home. $^{11}$

The fixed-effect specification requires some households to change their savings rate and have kids leave home. If few households revisit their participation and contribution decisions, the fixed-effects model sample size may be quite small. But a finding that households rarely change their deferrals will lend support to the hypothesis that households increase their per capita consumption when the kids leave home. In essence, the fixed-effects model compares the change in the contribution rate of those whose resident kid status does not change with the change in the contribution rate of those whose kids leave home.

\section{Results}

Table 4 presents results from the HRS analysis separately for the three definitions of kids leaving home described above. In general, the pooled-cross-section results show a small but statistically significant increase in 401(k) contributions when comparing households where the kids have left to households where the kids have not left. The size of the increase depends on the

\footnotetext{
${ }^{11}$ This possibility is suggested by Honig and Dushi (2009).
} 
definition of resident kids being considered. When only kids residing in the household are considered (specification 1), the increase is equal to 0.6 percentage points and is statistically significant. However, when the definition is expanded to include students as well as residents, the effect is about halved to 0.3 percent, although this specification is not statistically significant (specification 3). Finally, under the third definition of kids leaving home - which excludes kids who have left the home and spent some time out of school (even if they re-enroll) - a statistically significant increase of 0.5 percentage points is observed (specification 5). The other coefficients in the regressions are generally intuitive - households headed by minorities contributed less while households headed by older workers or more educated workers contribute more. The fixed-effect results show a smaller response of the kids leaving, ranking from a decrease in contributions under the second definition of kids leaving (specification 4) to an increase of less than 0.2 percentage points under the first (specification 2).

Table 5 reports the SIPP results with specification 1 including minimal controls and specification 2 including a more complete set of controls and panel dummies. The results are fairly consistent with those from the HRS. Both specifications indicate that households with kids over 23 - a control approximating having children above college age - contribute significantly more than households where the youngest child is aged 0-18. In the first specification, these households contribute 0.3 percentage points more to their 401(k)s than those with younger children and in the second specification 0.7 percentage points more. In both specifications, households that never had kids save more in their 401(k)s than households with kids - roughly 0.5-0.6 percent of salary more. This result is consistent with the HRS results using the second and third definition of having kids in residence. As in the HRS, minority-headed households contribute less to their 401(k)s, while older workers and the more educated workers contribute significantly more. ${ }^{12}$

The HRS and SIPP both seem to tell a similar story - households contribute perhaps 0.3 percent to at most 1.0 percent more to their 401(k)s when the kids leave home. But does this answer the question this paper set out to address: do households cut their consumption significantly when the kids leave? While many of the results above are statistically significant,

\footnotetext{
${ }^{12}$ In results not shown, these same regressions were run on the public-use SIPP using self-reported contribution rates and also controlling for the self-reported employer match rate. These results were almost identical to the ones presented here and are available on request.
} 
the increase in saving is small compared to that produced by models that assume the marginal utility of consumption drops when the kids leave. For example, consider a household with two adults and two kids making $\$ 100,000$ and contributing 6 percent of their salary to their 401(k). Under the assumptions of the typical model where kids increase the marginal utility of consumption, this household's 401(k) contributions would be expected to increase - at a minimum - all the way to the 401(k) deferral limit of \$18,000 in 2015 or 18 percent of earnings, a 12-percentage point increase. Yet the results showed only a 0.3 to 1.0 percentage point increase.

Are Households Saving Elsewhere?

Although the focus of this paper is on 401(k) saving, households may increase savings in response to the kids leaving in other ways. In addition to the examination of 401(k) deferrals, we investigated two such avenues for increased saving: 1) increases in non-401(k) financial assets and 2) repayment of the mortgage. Although several models similar to equation (1) were estimated using non-401(k) financial assets, none resulted in a statistically significant result so we focus on the second avenue, repayment of the mortgage. ${ }^{13}$

To investigate whether households accelerated the repayment of mortgage debt when the kids left home, equation (1) was re-estimated on a subsample of the HRS households used in Table 4 - only those owning their home. In this probit regression, the dependent variable took the value of one if the household held a mortgage and zero if it owned their home mortgagefree. ${ }^{14}$ As shown in Table 6, after controlling for age, length of housing tenure, and socioeconomic status, we found that individuals whose kids have left home are 7.3, 7.8, and 8.1 percentage points less likely to have a mortgage, depending on the definition of kids leaving home. These differences are significant at the one-percent level. It is unclear whether these differences reflect lump-sum mortgage prepayments, the net effect of higher mortgage payments made after the kids have left, trading down to a smaller home purchased outright, or some other factor.

\footnotetext{
${ }^{13}$ These models used different measures of non-401(k) wealth including the year-over-year change in wealth or a dummy variable indicating a positive change in non-401(k) wealth.

${ }^{14}$ Regressions using the amount paid to the mortgage, the amount paid relative to income, the remaining amount of the mortgage, and the remaining amount of the mortgage relative to the house value were also estimated. All of these regressions turned up no effect, possibly due to noise in the underlying dependent variables.
} 
But is this increase in saving as large as the one suggested by the life-cycle model? To perform a simple back of the envelope calculation, we assume the reduced prevalence of mortgage debt is solely the result of increased payments. In the wave before the kids left for good, 58.0 percent of HRS households had a mortgage, with an average balance of 1.1 times income. ${ }^{15}$ The estimates show that the kids leaving is associated with a 7.3 percentage point reduction in the probability of having a mortgage, or 12.6 percent of households with a mortgage (7.3 divided by 58.0 percent with a mortgage). Averaged over all households with mortgages, this amounts to 14 percent of income (1.1 times income times 12.6 percent). But the annual saving equals the total saving of 14 percent divided by the period from the kids leaving home to the age of retirement. On average, the kids left home when the household head was age 57. Assuming an average retirement age of $64^{16}$ this yields a period of 7 years and annual savings of 2 percent (14 percent of income divided by 7 years), far short of the 20 percent increase predicted under the life-cycle model. ${ }^{17}$

\section{Conclusion}

Assessments of the adequacy of retirement savings depend crucially on whether households cut consumption and increase saving when the kids leave home. Using data from the HRS and SIPP, we find evidence of only small increases in 401(k) contributions when the kids leave. These increases, while often statistically significant, fall far short of the predictions of models that assume the marginal utility of consumption drops considerably when the kids leave. Furthermore, savings does not seem to be increasing through increases in non-401(k) wealth and at most slightly through increased mortgage payments. Our findings support the view that the retirement saving crisis is real, as the evidence suggests that households do not increase their savings very much even when the kids leave home. Instead, they hold total consumption relatively constant, thereby increasing per-capita consumption. This response would be fine if households had adequate savings. But most households in their 40s and 50s have saved very little for retirement. Saving little while the kids are at home and then continuing to save little

\footnotetext{
${ }^{15}$ Using the first definition of the kids leaving and excluding eight households who had mortgage debt to income ratios over 20.

${ }^{16}$ The average retirement age for males (Munnell 2015).

${ }^{17}$ The same analysis was conducted in the public-use version of the SIPP but is not included for two reasons: 1) the results were not statistically significant and 2) the SSB data used in this paper do not contain data on whether the household owns a mortgage.
} 
after they have left puts households on track to enter retirement with insufficient resources to maintain their standard of living.

However, we acknowledge this may not be the final word on the subject. First, HRS non-401(k) wealth data may be too noisy, so that although households respond to the kids leaving by increasing saving through non-401(k) wealth, it was not picked up here. Second, it is plausible that a considerable lag may occur between the cessation of child-related expenses and an increase in 401(k) contributions. Even in the HRS, the panel may not be long enough to observe a response, especially for HRS cohorts that entered the sample later. Third, our data may not permit us to identify the cessation of child-related expenses with sufficient precision. Parents may continue to support their kids after they have graduated and left home and may only increase their savings once their kids have been launched into adult life. However, given that 401(k) plans represent the majority of individual retirement saving for a majority of workers, the lack of a large increase in contributions is one more data point in the debate on retirement preparedness. 


\section{References}

Citro, Constance F., and Robert T. Michael, eds. 1995. Measuring Poverty: A New Approach. Washington, DC: National Academy Press.

Coe, Norma B., and Anthony Webb. 2010. "Children and Household Utility: Evidence from Kids Flying the Coop” Working Paper 2010-16. Chestnut Hill, MA: Center for Retirement Research at Boston College.

Mitchell, Olivia S. and James F. Moore. 1997. "Projected Retirement Wealth and Savings Adequacy in the Health and Retirement Study.” Working Paper 6240. Cambridge, MA: National Bureau of Economic Research.

Munnell, Alicia H., Anthony Webb, and Luke Delorme. 2006. “A New National Retirement Risk Index.” Issue in Brief 48. Chestnut Hill, MA: Center for Retirement Research at Boston College.

Munnell, Alicia H., Natalia Orlova, and Anthony Webb. 2013. "How Important Is Asset Allocation to Financial Security in Retirement?” In The Market for Retirement Financial Advice, edited by Olivia S. Mitchell and Kent Smetters, 89-106. Oxford, United Kingdom: Oxford University Press.

Munnell, Alicia H., Matthew S. Rutledge, and Anthony Webb. 2014. “Are Retirees Falling Short? Reconciling the Conflicting Evidence” Working Paper 2014-16. Chestnut Hill, MA: Center for Retirement Research at Boston College.

Munnell, Alicia H. 2015. “The Average Retirement Age - An Update.” Issue in Brief 15-4. Chestnut Hill, MA: Center for Retirement Research at Boston College.

Palmer, Bruce A. 2008. “2008 GSU/Aon RETIRE Project Report.” Research Report Series 08-1. Atlanta, GA: J Mack Robinson College of Business at Georgia State University.

Rottke, Simon and Alexander Klos. 2013. "Saving and Consumption When Children Move Out.” German Economic Association Annual Conference.

Scholz, John K., Ananth Seshadri, and Surachai Khitatrakun. 2006. “Are Americans Saving ‘Optimally’ for Retirement?” Journal of Political Economy 114(4): 607-643.

Scholz, John K. and Ananth Seshadri. 2007. “Children and Household Wealth.” Working Paper 2007-158. Ann Arbor, MI: University of Michigan Retirement Research Center.

Scholz, John K. and Ananth Seshadri. 2008. “Are All Americans Saving 'Optimally’ for Retirement?” Presented at the $10^{\text {th }}$ Annual Joint Conference of the Retirement Research Consortium in Washington DC, August 7-8. 
Smith, Karen E., Richard W. Johnson, and Leslie Muller. 2004. "Deferring Income in EmployerSponsored Retirement Plans: The Dynamics of Participant Contributions” National Tax Journal 57(3): 639-670.

U.S. Census Bureau. SIPP Synthetic Beta: Version 6.0 [Computer file].Washington DC; Cornell University, Synthetic Data Server [distributor], Ithaca, NY, 2015.

Utkus, Stephen and Jean Young. 2009. “Inertia and Retirement Savings: Participant Behavior in 2008” Valley Forge, PA: Vanguard Center for Retirement Research. 
Table 1. Number of Households by Kid Residence Status, under Different Definitions of Residence

\begin{tabular}{lcccc}
\hline & & \multicolumn{3}{c}{ During time in sample } \\
\cline { 3 - 5 } & Never had children & $\begin{array}{c}\text { Children never in } \\
\text { residence }\end{array}$ & $\begin{array}{c}\text { Children always } \\
\text { in residence }\end{array}$ & $\begin{array}{c}\text { Children move } \\
\text { in/out }\end{array}$ \\
\hline Definition 1 & 130 & 1,235 & 562 & 1,367 \\
Definition 2 & 130 & 758 & 712 & 1,724 \\
Definition 3 & 130 & 1,111 & 693 & 1,390 \\
\hline
\end{tabular}

Notes: Definition 1 is having kids are physically living at home; Definition 2 is having kids physically living at home or in school; and Definition 3 is having kids physically living at home or in school and who never ceased living at home or school.

Source: Authors' calculations from Waves 1-10 of the Health and Retirement Survey (HRS). 
Table 2. Descriptive Statistics for HRS Married Households

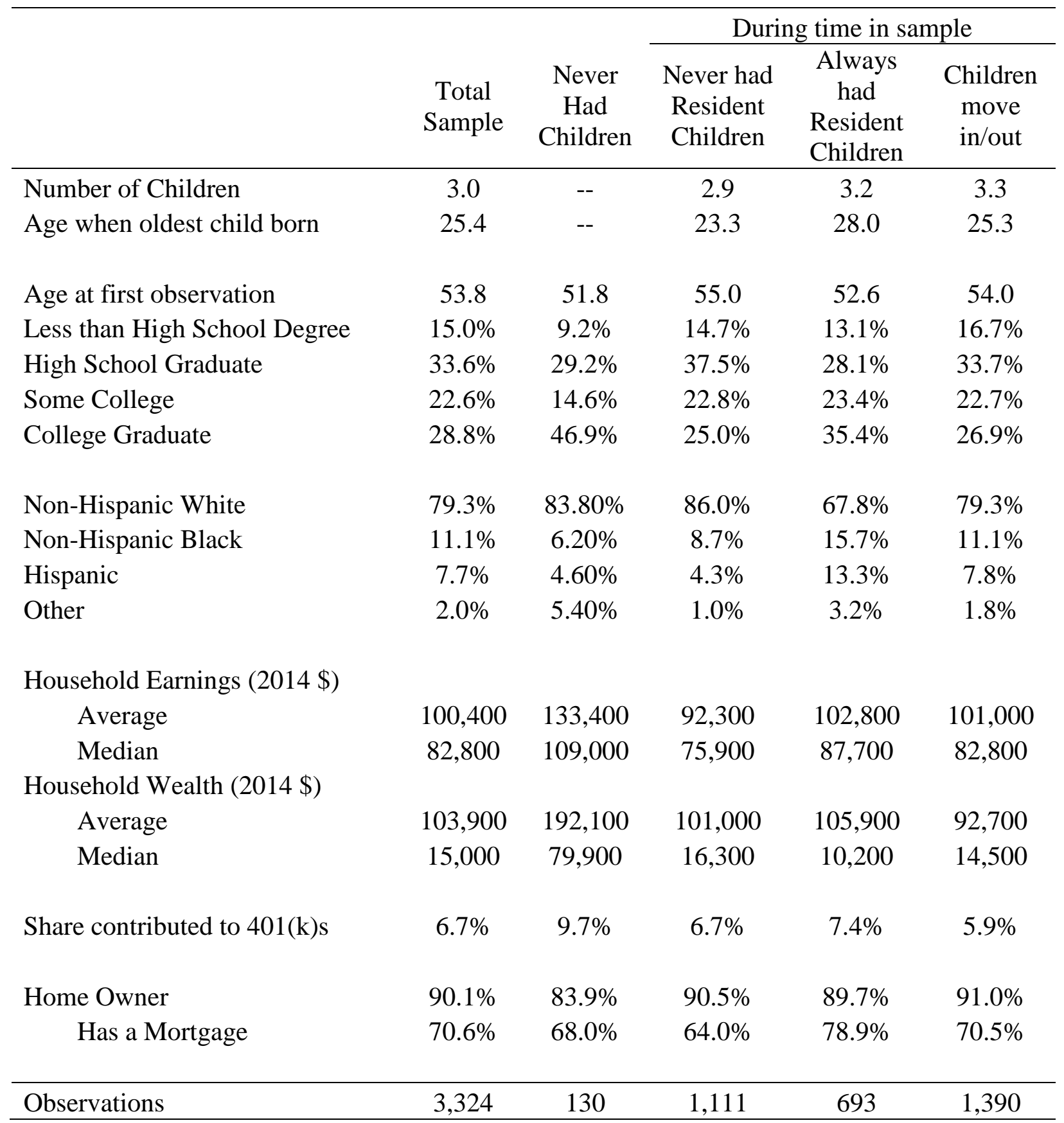

Note: All variables refer to the male in the married couple.

Source: Authors' calculations from Waves 1-10 of the HRS. 
Table 3. Descriptive Statistics for SIPP Married Households

\begin{tabular}{|c|c|c|c|c|c|}
\hline & \multirow[b]{2}{*}{ Overall } & \multirow[b]{2}{*}{ Never kids } & \multicolumn{3}{|c|}{ Age of youngest child } \\
\hline & & & Under 18 & $19-22$ & 23 and over \\
\hline Number of kids & 1.8 & -- & 2.2 & 2.3 & 2.3 \\
\hline Age when oldest kid born & 26.9 & -- & 27.9 & 26.1 & 24.5 \\
\hline Age at interview & 45.1 & 41.3 & 41.2 & 51.5 & 57.3 \\
\hline Less than high school degree & $5.7 \%$ & $3.7 \%$ & $5.4 \%$ & $7.0 \%$ & $8.2 \%$ \\
\hline High school graduate & $25.8 \%$ & $22.2 \%$ & $25.5 \%$ & $27.3 \%$ & $29.8 \%$ \\
\hline Some college & $31.8 \%$ & $31.7 \%$ & $31.7 \%$ & $31.9 \%$ & $32.1 \%$ \\
\hline College graduate & $36.7 \%$ & $42.4 \%$ & $37.4 \%$ & $33.8 \%$ & $31.7 \%$ \\
\hline Non-Hispanic white & $87.4 \%$ & $90.8 \%$ & $85.1 \%$ & $88.1 \%$ & $90.1 \%$ \\
\hline Non-Hispanic black & $6.5 \%$ & $5.0 \%$ & $7.0 \%$ & $6.5 \%$ & $6.5 \%$ \\
\hline Hispanic & $6.1 \%$ & $4.2 \%$ & $7.8 \%$ & $5.3 \%$ & $3.3 \%$ \\
\hline \multicolumn{6}{|l|}{ Household earnings (2014 \$) } \\
\hline Average & $\$ 117,000$ & $\$ 113,500$ & $\$ 120,000$ & $\$ 122,500$ & $\$ 110,000$ \\
\hline Median & $\$ 90,000$ & $\$ 89,500$ & $\$ 91,500$ & $\$ 95,500$ & $\$ 89,369$ \\
\hline Homeowner & $82.9 \%$ & $73.4 \%$ & $82.3 \%$ & $89.4 \%$ & $91.1 \%$ \\
\hline Share contributed 401k(s) & $4.0 \%$ & $4.1 \%$ & $3.6 \%$ & $4.2 \%$ & $5.0 \%$ \\
\hline Observations & 40,388 & 7,834 & 21,456 & 3,718 & 7,380 \\
\hline
\end{tabular}

Note: All variables refer to the male in the married couple.

Source: Survey of Income and Program Participation (SIPP), 1992-2008 Panels. 
Table 4. HRS Regression of Share of Household Earnings Contributed to 401k Plans

\begin{tabular}{|c|c|c|c|c|c|c|c|c|c|c|c|c|}
\hline & \multicolumn{3}{|c|}{ Definition 1} & \multicolumn{5}{|c|}{ Definition 2} & \multicolumn{4}{|c|}{ Definition 3} \\
\hline & OLS & & FE & & OLS & & FE & & OLS & & FE & \\
\hline \multirow[t]{2}{*}{ Children not in home } & 0.614 & $* * *$ & 0.155 & & 0.264 & & -0.162 & & 0.479 & ** & 0.059 & \\
\hline & $(0.234)$ & & $(0.307)$ & & $(0.232)$ & & $(0.262)$ & & $(0.233)$ & & $(0.310)$ & \\
\hline Never had children & $\begin{array}{r}1.566 \\
(0.737) \\
\end{array}$ & ** & & & $\begin{array}{r}1.952 \\
(0.737) \\
\end{array}$ & $* * *$ & & & $\begin{array}{r}2.065 \\
(0.738)\end{array}$ & $* * *$ & & \\
\hline \multicolumn{13}{|l|}{ Demographics } \\
\hline Black & $\begin{array}{r}-2.335 \\
(0.314)\end{array}$ & $* * *$ & & & $\begin{array}{r}-2.368 \\
{[0.3154]}\end{array}$ & $* * *$ & & & $\begin{array}{r}-2.349 \\
(0.315)\end{array}$ & $* * *$ & & \\
\hline Hispanic & $\begin{array}{r}-1.439 \\
(0.368)\end{array}$ & $* * *$ & & & $\begin{array}{r}-1.497 \\
(0.367)\end{array}$ & & & & $\begin{array}{r}-1.468 \\
(0.367)\end{array}$ & $* * *$ & & \\
\hline Age & $\begin{array}{r}1.264 \\
(0.191)\end{array}$ & $* * *$ & $\begin{array}{r}1.158 \\
(0.307)\end{array}$ & $* * *$ & $\begin{array}{r}1.272 \\
(0.191)\end{array}$ & $* * *$ & $\begin{array}{r}1.176 \\
(0.415)\end{array}$ & $* * *$ & $\begin{array}{r}1.272 \\
(0.191)\end{array}$ & $* * *$ & $\begin{array}{r}1.164 \\
(0.416)\end{array}$ & $* * *$ \\
\hline $\mathrm{Age}^{2}$ & $\begin{array}{l}-0.011 \\
(0.002)\end{array}$ & $* * *$ & $\begin{array}{l}-0.011 \\
(0.003)\end{array}$ & $* * *$ & $\begin{array}{r}-0.011 \\
{[0.0016]}\end{array}$ & $* * *$ & $\begin{array}{r}-0.011 \\
(0.003)\end{array}$ & $* * *$ & $\begin{array}{r}-0.012 \\
(0.002)\end{array}$ & $* * *$ & $\begin{array}{r}-0.011 \\
(0.003)\end{array}$ & $* * *$ \\
\hline \multicolumn{13}{|l|}{ Education } \\
\hline Less than high school & $\begin{array}{r}-2.690 \\
0.356\end{array}$ & $* * *$ & & & $\begin{array}{r}-2.68778 \\
(0.356)\end{array}$ & $* * *$ & & & $\begin{array}{r}-2.699 \\
(0.356)\end{array}$ & $* * *$ & & \\
\hline High school & $\begin{array}{r}-2.369 \\
(0.303)\end{array}$ & $* * *$ & & & $\begin{array}{r}-2.34682 \\
(0.304)\end{array}$ & $* * *$ & & & $\begin{array}{r}-2.369 \\
(0.304)\end{array}$ & $* * *$ & & \\
\hline Some college & $\begin{array}{l}-1.997 \\
(0.313)\end{array}$ & $* * *$ & & & $\begin{array}{r}-1.974 \\
(0.303)\end{array}$ & $* * *$ & & & $\begin{array}{r}-1.992 \\
(0.313)\end{array}$ & $* * *$ & & \\
\hline \multicolumn{13}{|l|}{ Earnings \& Wealth } \\
\hline Log of earnings & $\begin{array}{r}0.790 \\
(0.157)\end{array}$ & $* * *$ & $\begin{array}{r}0.298 \\
(0.179)\end{array}$ & * & $\begin{array}{r}0.786 \\
(0.157)\end{array}$ & $* * *$ & $\begin{array}{r}0.294 \\
(0.180)\end{array}$ & & $\begin{array}{r}0.790 \\
(0.157)\end{array}$ & $* * *$ & $\begin{array}{r}0.297 \\
(0.179)\end{array}$ & $*$ \\
\hline Log net financial wealth & $\begin{array}{r}0.203 \\
(0.024)\end{array}$ & $* * *$ & $\begin{array}{r}0.056 \\
(0.025)\end{array}$ & $* *$ & $\begin{array}{r}0.247 \\
(0.024)\end{array}$ & $* * *$ & $\begin{array}{r}0.057 \\
(0.025)\end{array}$ & $* *$ & $\begin{array}{r}0.245 \\
(0.024)\end{array}$ & $* * *$ & $\begin{array}{r}0.057 \\
(0.025)\end{array}$ & $* *$ \\
\hline Has mortgage & $\begin{array}{l}-0.241 \\
(0.240)\end{array}$ & & $\begin{array}{l}-0.040 \\
(0.291)\end{array}$ & & $\begin{array}{r}-2.640 \\
(0.239)\end{array}$ & & $\begin{array}{r}-0.041 \\
(0.292)\end{array}$ & & $\begin{array}{r}-0.256 \\
(0.239)\end{array}$ & & $\begin{array}{r}-0.044 \\
(0.292)\end{array}$ & \\
\hline Constant & $\begin{array}{r}-38.099 \\
(5.961)\end{array}$ & $* * *$ & $\begin{array}{r}-29.201 \\
14.975\end{array}$ & $*$ & $\begin{array}{r}-38.264 \\
(5.964)\end{array}$ & $* * *$ & $\begin{array}{r}-29.766 \\
(14.984)\end{array}$ & $* *$ & $\begin{array}{r}-38.284 \\
(5.958)\end{array}$ & $* * *$ & $\begin{array}{r}-29.372 \\
(15.000)\end{array}$ & $* *$ \\
\hline Number of observations & 10,843 & & 10,843 & & 10,843 & & 10,843 & & 10,843 & & 10,843 & \\
\hline
\end{tabular}

Notes: Significance is indicated to the 1-percent level (***), 5-percent level $(* *)$ and 10-percent level $(*)$. All variables refer to male in the couple. Definition 1 is having kids are physically living at home; Definition 2 is having kids physically living at home or in school; and Definition 3 is having kids physically living at home or in school and who never ceased living at home or school. All regressions also control for the HRS wave.

Source: Authors' calculations from Waves 1-10 of the HRS. 
Table 5. SIPP Regression of Share of Household Earnings Contributed to 401k Plans

\begin{tabular}{|c|c|c|}
\hline & (1) & (2) \\
\hline Youngest kid 19-22 & -0.126 & 0.030 \\
\hline (Base case = 0-18) & $(0.082)$ & $(0.079)$ \\
\hline Youngest kid 23+ & $0.256^{* * *}$ & $0.718 * * *$ \\
\hline (Base case=0-18) & $(0.091)$ & $(0.089)$ \\
\hline & $0.472 * * *$ & $0.553 * * *$ \\
\hline Never had kids & $(0.065)$ & $(0.061)$ \\
\hline \multirow{2}{*}{ Age } & $0.074 * * *$ & $0.054 * * *$ \\
\hline & $(0.003)$ & $(0.003)$ \\
\hline \multirow{2}{*}{ Black non-Hispanic } & & $-0.750 * * *$ \\
\hline & & $(0.088)$ \\
\hline \multirow{2}{*}{ Hispanic } & & $-0.418 * * *$ \\
\hline & & $(0.092)$ \\
\hline \multirow{2}{*}{$\begin{array}{l}\text { High school graduate } \\
\text { (Base case = drop out) }\end{array}$} & & $0.420 * * *$ \\
\hline & & $(0.123)$ \\
\hline Some college & & $0.839 * * *$ \\
\hline (Base case = drop out) & & $(0.109)$ \\
\hline \multirow{2}{*}{$\begin{array}{l}\text { College graduate } \\
\text { (Base case = drop out) }\end{array}$} & & $1.51 * * *$ \\
\hline & & $(0.131)$ \\
\hline \multirow{2}{*}{ Log of earnings } & & $0.874 * * *$ \\
\hline & & $(0.043)$ \\
\hline \multirow{2}{*}{ DB pension available } & & $0.223 * * *$ \\
\hline & & $(0.043)$ \\
\hline \multirow{2}{*}{ Individual owns residence } & & $0.717 * * *$ \\
\hline & & $(0.057)$ \\
\hline \multirow{2}{*}{ Constant } & $0.517 * * *$ & $-10.672 * * *$ \\
\hline & $(0.114)$ & $(0.044)$ \\
\hline Panel controls? & No & Yes \\
\hline Number of observations & 40,388 & 40,388 \\
\hline
\end{tabular}

Notes: Significance is indicated to the 1-percent level $(* * *)$, 5-percent level $(* *)$ and 10 -percent level $(*)$. All variables refer to the male member of the married couple.

Source: SIPP, 1992-2008 Panels. 
Table 6. HRS Marginal Effects Regression on Probability of Still Having a Mortgage

\begin{tabular}{|c|c|c|c|}
\hline & Definition 1 & Definition 2 & Definition 3 \\
\hline \multirow[t]{2}{*}{ Children not in home } & $-0.073 * * *$ & $-0.078 * * *$ & $-0.081 * * *$ \\
\hline & $(0.015)$ & $(0.013)$ & $(0.014)$ \\
\hline \multirow[t]{2}{*}{ Never had children } & 0.040 & -0.026 & -0.035 \\
\hline & $(0.039)$ & $(0.039)$ & $(0.039)$ \\
\hline \multicolumn{4}{|l|}{ Demographics } \\
\hline \multirow[t]{2}{*}{ Black } & $0.08 * * *$ & $0.073 * * *$ & $0.078 * * *$ \\
\hline & $(0.026)$ & $(0.026)$ & $(0.026)$ \\
\hline \multirow[t]{2}{*}{ Hispanic } & 0.008 & 0.005 & 0.005 \\
\hline & $(0.031)$ & $(0.031)$ & $(0.031)$ \\
\hline \multirow[t]{2}{*}{ Age } & 0.014 & 0.012 & 0.014 \\
\hline & $(0.014)$ & (0.014) & (0.014) \\
\hline \multirow[t]{2}{*}{$\mathrm{Age}^{2}$} & 0.000 & 0.000 & $0.000 *$ \\
\hline & $(0.000)$ & $(0.000)$ & $(0.000)$ \\
\hline \multicolumn{4}{|l|}{ Education } \\
\hline \multirow[t]{2}{*}{ Less than high school } & $-0.149 * * *$ & $-0.145 * * *$ & $-0.148 * * *$ \\
\hline & $(0.025)$ & $(0.025)$ & $(0.025)$ \\
\hline \multirow[t]{2}{*}{ High school } & $-0.094 * * *$ & $-0.092 * * *$ & $-0.093 * * *$ \\
\hline & $(0.016)$ & $(0.017)$ & $(0.017)$ \\
\hline \multirow[t]{2}{*}{ Some college } & 0.014 & 0.014 & 0.015 \\
\hline & $(0.018)$ & $(0.018)$ & $(0.018)$ \\
\hline
\end{tabular}

Earnings \& wealth

Log of earnings

$$
0.051 * * *
$$

$0.050 * * *$

$0.051 * * *$

$(0.097)$

$(0.097)$

$(0.097)$

Log net financial wealth

$-0.044 * * *$

$-0.044 * * *$

$-0.044 * * *$

Log housing wealth

(0.003)

(0.003)

(0.003)

$0.142 * * *$

$0.143 * * *$

$0.142 * * *$

(0.010)

(0.010)

(0.010)

Housing tenure

$$
\begin{aligned}
& -0.014 * * * \\
& (0.006)
\end{aligned}
$$

$-0.014 * * *$

(0.006)

$-0.014 * * *$

(0.006)

Constant

Number of observations

7,482

7,482

7,482

Notes: Significance is indicated to the 1-percent level (***), 5-percent level (**) and 10-percent level (*). Source: Authors' calculations from Waves 1-10 of the HRS. 


\section{RECENT WORKING PAPERS FROM THE CENTER FOR RETIREMENT RESEARCH AT BOSTON COLLEGE}

Evaluating the Impact of Social Security Benefits on Health Outcomes Among the Elderly Padmaja Ayyagari, September 2015

Does Age-Related Decline in Ability Correspond with Retirement Age?

Anek Belbase, Geoffrey T. Sanzenbacher, and Christopher M. Gillis, September 2015

Job Polarization and Labor Market Outcomes for Older, Middle-Skilled Workers Matthew S. Rutledge and Qi Guan, September 2015

What Causes Workers to Retire Before They Plan? Alicia H. Munnell, Geoffrey T. Sanzenbacher, and Matthew S. Rutledge, September 2015

Calculating Neutral Increases in Retirement Age by Socioeconomic Status Geoffrey T. Sanzenbacher, Anthony Webb, Candace M. Cosgrove, and Natalia S. Orlova, August 2015

How Does Occupational Access for Older Workers Differ by Education? Matthew S. Rutledge, Steven A. Sass, and Jorge D. Ramos-Mercado, August 2015

How Much Longer Do People Need to Work?

Alicia H. Munnell, Anthony Webb, and Anqi Chen, August 2015

The Challenge of Pension Reform in Georgia: Non-Contributory Pensions and Elderly Poverty

Tamila Nutsubidze and Khatuna Nutsubidze, July 2015

The Transition from Defined Benefit to Defined Contribution Pensions: Does It Influence Elderly Poverty?

Natalia S. Orlova, Matthew S. Rutledge, and April Yanyuan Wu, July 2015

Will the Average Retirement Age Continue to Increase?

Matthew S. Rutledge, Christopher M. Gillis, and Anthony Webb, July 2015

The Role of Occupations in Differentiating Health Trajectories in Later Life Michal Engelman and Heide Jackson, University of Wisconsin-Madison, July 2015

The Relationship Between Automatic Enrollment and DC Plan Contributions: Evidence from a National Survey of Older Workers

Barbara A. Butrica and Nadia S. Karamcheva, July 2015

All working papers are available on the Center for Retirement Research website (http://crr.bc.edu) and can be requested by e-mail (crr@bc.edu) or phone (617-552-1762). 